\title{
Sources and leaching of nitrate contamination in groundwater
}

\author{
Saurabh Shukla* and Abhishek Saxena \\ Faculty of Civil Engineering, Institute of Technology, Shri Ramswaroop Memorial University, Barabanki 225 003, India
}

\begin{abstract}
Nitrate is an important and widespread contaminant of groundwater and surface water resources. Nitrate formed either by the natural processes (atmospheric fixation, lightning storms) or added through anthropogenic activities (fertilizer applications, septic tanks) enters the hydrosphere with virtual ease. In this article we review various concepts discussing the different sources behind elevated nitrate levels. Moreover, an attempt is also made towards preparing a comprehensive framework to understand the leaching of nitrate in groundwater. This framework would effectively help in understanding the origin and dynamics controlling the fate of nitrate in groundwater, which is vital for managing the associated risks and safeguarding the water supplies.
\end{abstract}

Keywords: Geogenic sources, groundwater pollution, methemoglobinemia, mineral weathering, nitrate contamination.

NitRATE $\left(\mathrm{NO}_{3}^{-}\right)$, the second most common chemical contaminant of groundwater after pesticides has attracted considerable attention ${ }^{1}$. Nitrate, nitrite $\left(\mathrm{NO}_{2}^{-}\right)$, ammonia $\left(\mathrm{NH}_{3}\right)$ and organically bound forms of nitrogen (Org-N) are the species of concern for water resource management in various parts of the world ${ }^{2-4}$. The background nitrate concentration (naturally occurring nitrate) in groundwater shall not exceed $10 \mathrm{mg} / \mathrm{l}$ and the levels exceeding this background limit are an indicator of nitrate contamination primarily through various anthropogenic activities 5 . Although this background concentration cannot be considered of pristine state $^{6}$, the contribution from geogenic sources of nitrate cannot be ignored.

Nitrate may enter the human body through endogenous and exogenous pathways, and it becomes toxic when nitrate is reduced to nitrite in the oral cavity ${ }^{7}$. In moderate amounts, nitrate is a harmless constituent of food and water, hence a permissible limit of $50 \mathrm{mg} / \mathrm{l}$ as nitrate ion (or $11 \mathrm{mg} / \mathrm{l}$ as nitrate-nitrogen) in drinking water is specified by the World Health Organization (WHO) to protect against methemoglobinemia in bottle-fed neonates $^{8}$. The Environmental Protection Agency (EPA) has set the maximum contaminant level as $10 \mathrm{mg} / \mathrm{l}$ of nitrate as nitrogen ${ }^{9}$ in the United States, whereas in India, the

*For correspondence. (e-mail: saurabh.shukla2020@gmail.com) acceptable limit by the Bureau of Indian Standard (BIS) is $45 \mathrm{mg} / \mathrm{l}$ as nitrate (IS 10500:2012).

Ingestion of water having nitrate concentration up to $45 \mathrm{mg} / \mathrm{l}$ has no severe health impact. Although the ingested concentration increases the probability of blue baby syndrome (methemoglobinemia) in bottle-fed neonates ${ }^{8}$, the older children (aged 1-7 years) are also affected by the blue baby syndrome ${ }^{10}$. Varying levels of ingested nitrate concentration and its possible adverse health impacts on humans and livestock population are presented in Figure 1. These health impacts depend upon the exposure duration and ingested concentration of nitrate. To ascertain possible and specific correlation, there is a need for comprehensive health impact surveys.

Presence of geogenic factors along with the anthropogenic sources makes understanding of sources of nitrate contamination difficult. Many researchers have reported the use of statistical tools, Geographical Information System (GIS) tools and isotopic analysis to identify the source of elevated nitrate levels in groundwater ${ }^{11-13}$. However, areas having similar geological and hydrological characteristics have shown different levels of contamination, which indicates the presence of complex bio-geochemical factors behind the elevated nitrate levels ${ }^{14,15}$. Moreover, the geogenic factors behind these elevated levels are somewhat neglected in earlier studies, hence an attempt is made in this paper to discuss the various sources and leaching mechanism behind the nitrate contamination. Comparisons are also made between the methodologies available for source identification/ differentiation. A comprehensive management framework is also proposed to be incorporated in further studies, which would not only help in understanding the origin, release mechanism and the complex dynamics behind the fate of nitrate in the groundwater, but also be vital for managing the associated health risks and safeguarding the affected water supplies.

\section{Sources of nitrate in various ecosystems}

The formation of nitrate is an integral part of the nitrogen cycle in our environment and it may reach the groundwater through either anthropogenic sources or geogenic sources. Globally, about 260 million tonnes of atmospheric nitrogen is fixed annually into the soil ${ }^{16}$ through 


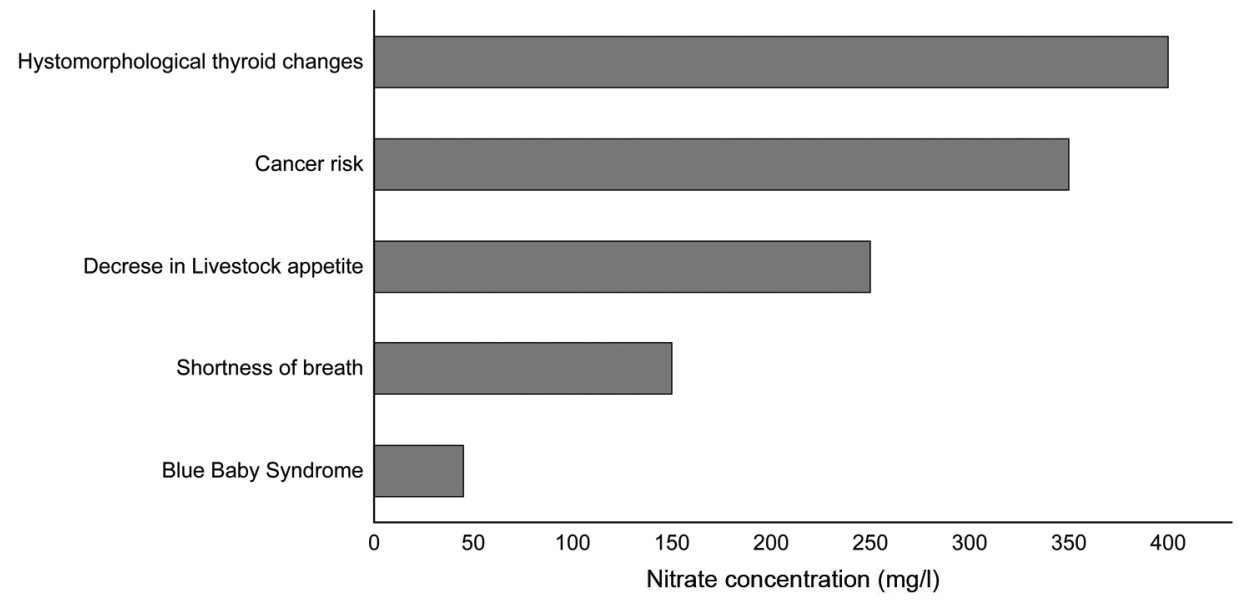

Figure 1. Concentration of ingested nitrate and subsequent health impacts (source: refs 28, 64, 66, 72, 73).

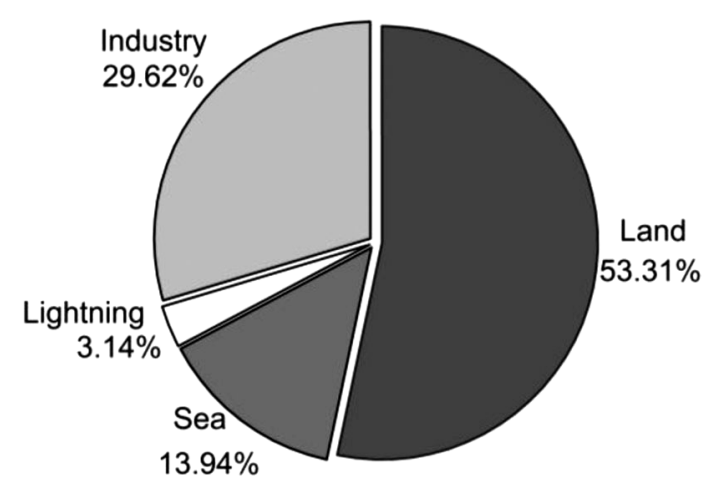

Figure 2. Estimated amounts of nitrogen fixed annually from different sources (after ref. 17).

biological and non-biological processes. Biological fixation accounts for 193 million tonnes of nitrogen per year (67.25\%), through land (legume and non-legume) and sea (Figure 2). The remaining 32.75\% is through nonbiological processes such as atmospheric lightning and industrial discharges ${ }^{17}$. The nitrogen fixed in the soil is further converted to nitrate and nitrite ${ }^{18}$. Nitrate also form due to the breaking down of fertilizers by microorganisms, decaying plants, manures or other organic residues, which further add nitrate in the soil ${ }^{19}$. Plants use this nitrate from soil to fulfill their nutrient requirements and may accumulate nitrate in their leaves and stems ${ }^{20}$. As the nitrate-containing compounds are generally soluble and easily migrate, heavy rain or irrigation water may subsequently cause leaching of these ions into the groundwater $^{3}$ (Figure 3).

The rapid increase in nitrate concentration has adverse effects on various ecosystems such as increase in $\mathrm{NO}_{x}$ emissions, algal blooms and subsequent eutrophication, etc. $^{21,22}$. The varying nitrogen accumulation potential (ability to retain the nitrogen within the respective ecosystem) and transfer potential (ability of the respective ecosystem to allow the migration of nitrogen into another ecosystem) is a good indicator of the risk of nitrate and nitrite contamination in these ecosystems. The comparison of this accumulation and transfer potential for various ecosystems is shown in Figure 4. It is evident here that, although atmosphere and agro-systems have low accumulation potential, the high transfer potential presents a risk of contamination in other ecosystems especially transferring into the groundwater. Similarly, high accumulation and high transfer potential of grasslands and forests present the risk of nitrate contamination in groundwater through anthropogenic interventions.

\section{Anthropogenic sources}

Various anthropogenic activities such as heavy fertilizer application, improper disposal of industrial waste, deforestation, poor construction of septic tanks and leaching pits, are mostly responsible for high values of nitrate infiltrating the groundwater regime (Figure 3). Among these, fertilizer application and subsequent leaching is considered the primary reason for nitrate contamination of shallow aquifers ${ }^{23,24}$ (Figure 5). Nitrogen is one of the major components of all inorganic fertilizers, usage of which has increased to achieve better crop yield. Over application and improper timing of applying the fertilizers may cause nitrate to leach into the groundwater ${ }^{25}$. Vinod et al. $^{26}$ reported nitrate concentration of up to $75 \mathrm{mg} / \mathrm{l}$ leaching from the irrigated lands in Karnataka, India. Similarly, Gheysari et $a .^{27}$ reported a $\mathrm{NO}_{3}^{-}-\mathrm{N}$ concentration in the range of $46-138 \mathrm{mg} / \mathrm{l}$. Intensive livestock farming and waste from cattle also cause nitrate contamination of groundwater ${ }^{28}$.

Leakage from sewers and septic tanks affects the underlying aquifers in majority of urban agglomerations around the world. The wastewater percolation to the aquifers can amount up to 100 million litres annually ${ }^{29}$. 


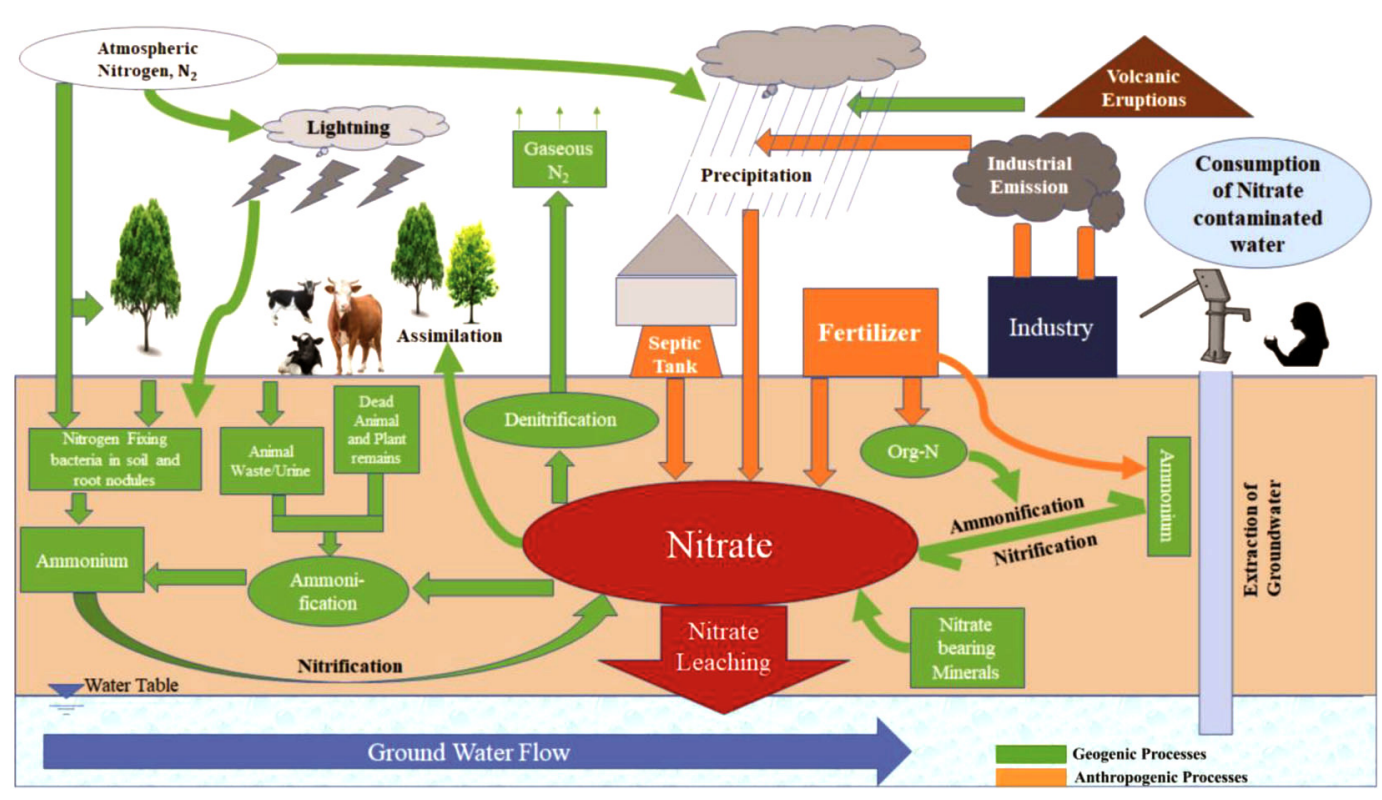

Figure 3. Formation and leaching of nitrate into the groundwater (source: refs 15, 37).

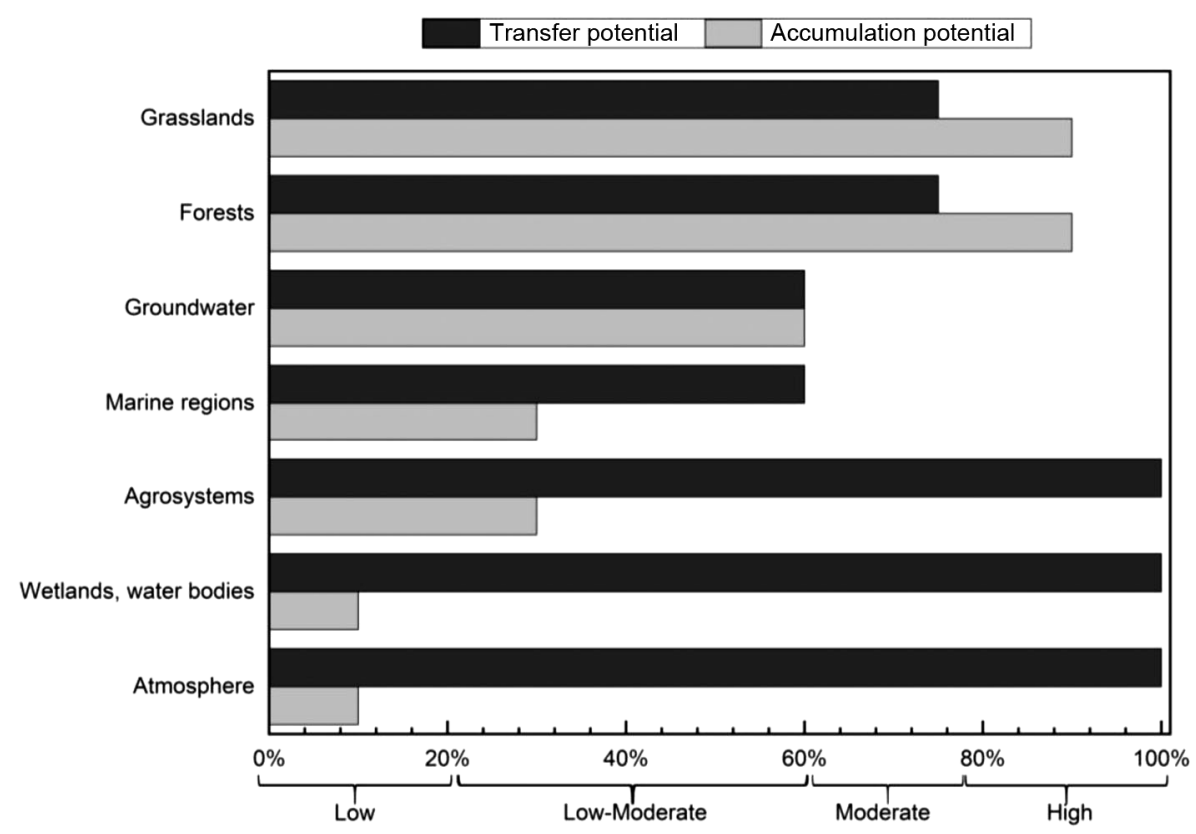

Figure 4. Nitrogen accumulation and transfer potential in different ecosystems (Source: refs 21, 63).

Nearly one-third of the population is connected with on-site sewage disposal (septic tanks, pit latrines) in the United States, Canada, Australia, Florida and many developing countries ${ }^{14,30}$. Various numerical and GIS-based models (TOUGHREACT-N, ArcNLET, MANAGE, TNT2, etc.) have been developed to stimulate the fate of nitrate through these on-site disposal systems. These models primarily rely on analytical equations describing the transport of nitrate in the groundwater and consider advection, hydrodynamic dispersion and denitrification processes for stimulation ${ }^{30,31}$. The results of these models suggest a nitrate load of up to $2.5 \mathrm{~kg} /$ day from the septic tanks ${ }^{30}$ which leaches down to the aquifer. Other studies have reported an average nitrogen load of up to $25-$ $60 \mathrm{mg} / \mathrm{l}$, and $60 \%$ of this nitrogen is assumed to be converted to nitrate which reaches the aquifer system ${ }^{14,30}$.

Various nitrogen-containing compounds such as (i) anhydrous ammonia, (ii) nitric acid, (iii) urea, etc. are extensively used in textile industry, dye manufacturing and metal processing industries. Mismanagement and improper disposal of the wastes from these industries may also add to nitrate contamination in groundwater ${ }^{32,33}$. Nitrogen 
is also a major constituent in the manufacturing of explosives, utilizing the ammonium nitrate ${ }^{34}$, inadequate waste handling and affected disposal streams from these industries may add the nitrate into the aquifer systems ${ }^{14,34}$.

Apparently, these anthropogenic factors contribute substantially in the places of high rate of fertilizer application, ample rainfall, light textured soil and shallow water table, towards elevated nitrate concentrations in groundwater. Contaminated landfills, urban fertilizer use (in-house gardening, recreational grasslands, etc.), and construction of buildings also contribute to the on-ground nitrate loading in small quantities ${ }^{14}$.

\section{Geogenic sources}

Ammonification, nitrification and denitrification are the governing natural processes behind the nitrate formation in soil. The gaseous nitrogen from the atmosphere is fixed and added to the soil as ammonia through lightning storms, and bacteria present in soil and root nodules of plants. Moreover, the nitrogen from volcanic eruptions is also added to soil through precipitation. Similarly, the wastes from animals, dead remains of plants and animals also undergo ammonification in the soil. This ammonia undergoes nitrification/ammonia oxidation (action of nitrifying bacteria such as nitrosomonas and nitrobacter) to form nitrate ${ }^{15,21}$. The excess nitrogen and nitrate may reach the surface water bodies and cause eutrophication ${ }^{15}$. This nitrate also leaches down to the aquifer systems and contaminates the groundwater. However, the nitrate contribution from these natural processes is small, and very difficult to estimate, as the nitrate may undergo denitrification (action of denitrifying bacteria such as Pseudomonas) and gets converted to nitrogen gas. Moreover, the nitrate may also be assimilated by plants for their nutritional requirement (Figure 3). The extent of assimilation and denitrification primarily governs the background nitrate concentration in the aquifer systems ${ }^{35}$.

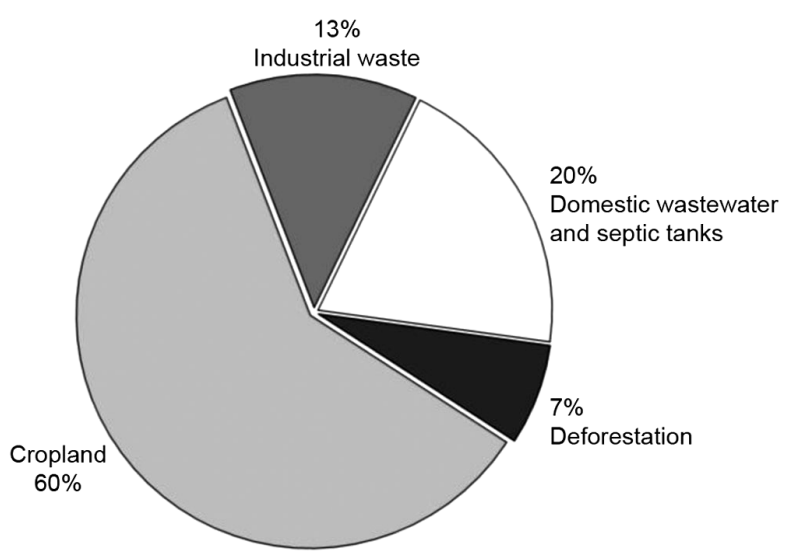

Figure 5. Anthropogenic sources of nitrate contamination in groundwater (source: refs 2, 57).
Further, there are several minerals in aquifer strata (tobelite, nitre, nitratine, etc.), having nitrogen in their lattice, which undergo the process of weathering and creates probability of releasing the nitrogen from their lattice $^{36}$. This nitrogen may further be converted to nitrate and subsequently contaminate the groundwater ${ }^{37}$. Gupta et $a{ }^{38}{ }^{38}$ found high nitrate concentrations in the 'river bank filtration well' as well as in the groundwater samples from several zones of Srinagar and Srikot area. Water in the affected sites was exposed to zones of phyllites and quartzite bedrocks in the region, and the isotopic composition of nitrate in water samples and leachates obtained from the bedrocks were found similar, indicating that nitrate is originating in the groundwater through weathering and subsequent leaching from these bedrocks. Power et $a l .{ }^{39}$ found that approximately $200 \mathrm{~kg} / \mathrm{ha}$ of ammonium existed in a $1 \mathrm{~m}$ thickness of the Paleocene Fort Union Shale in North Dakota and eastern Montana, which was found to be rapidly nitrified to nitrate under favourable moisture, temperature and oxygen concentration.

Several other factors like, nature and thickness of surface deposits, rainfall quantity and distribution, depth to the groundwater level, distribution of vegetation types and presence of nitrogen-fixing vegetation ${ }^{15,36,38}$, all contribute towards the elevated levels of nitrate in the groundwater.

It is well established that contribution of geogenic sources of nitrate in groundwater is smaller when compared with anthropogenic sources, but its importance cannot be ignored in a comprehensive study. Hence, detailed studies incorporating the assessment of geogenic sources must also be conducted to identify the precise source and release mechanism of nitrate in groundwater. Furthermore, based on the studies cited here, Table 1 presents the origin of nitrate in groundwater and possible range of nitrate concentration from the respective source.

\section{Proposed comprehensive framework for source identification}

Nitrate contamination in groundwater primarily is a function of on-ground nitrogen loading ${ }^{40}$. However, the source identification and/or differentiation is complex and hence, requires a framework to identify the possible source. Almasri $^{40}$ has proposed a detailed conceptual management framework; but the framework discusses only the management options in detail and does not specifically deal with source identification. The framework with mathematical modelling, wherein great attention is required for data collection (both qualitatively and quantitatively), is time consuming, requires skilled manpower, which might not be feasible in all the studies. Time constraint is also important, as many of these areas will already be looking for alternate water supply options. Variability of data 
Table 1. Concentration of nitrate in groundwater from various sources

\begin{tabular}{|c|c|c|}
\hline Origin of nitrate & Concentration range & Remarks \\
\hline Background level $^{5}$ & $<5-10 \mathrm{mg} / 1$ & Samples collected from wells in forest areas \\
\hline Agricultural practices $\mathrm{s}^{\mathrm{b}, 25-28,56}$ & $5-800 \mathrm{mg} / 1$ & Very highly variable \\
\hline \multirow[t]{2}{*}{ Septic tanks/leaching pits ${ }^{29,30,57-59}$} & Not detected $-300 \mathrm{mg} / 1$ & Moderately variable \\
\hline & & $\begin{array}{l}\text { Sometimes values up to as high as } 500 \mathrm{mg} / \mathrm{l} \\
\text { were also reported }^{\text {a }}\end{array}$ \\
\hline Leaky sewers ${ }^{14,29,30}$ & $10-50 \mathrm{mg} / 1$ & Variable \\
\hline \multirow[t]{2}{*}{ Deforestation $^{\mathrm{b}, 60,61}$} & $3-15 \mathrm{mg} / 1$ & Depending upon soil depth \\
\hline & $150-400 \mathrm{mg} / 1$ & Only for brief periods after rain \\
\hline Contaminated land $\mathrm{d}^{\mathrm{b}, 62}$ & $10-20 \mathrm{mg} / 1$ & - \\
\hline \multirow[t]{2}{*}{ Industrial applications ${ }^{34}$} & $20-100 \mathrm{mg} / 1$ & - \\
\hline & $250 \mathrm{mg} / \mathrm{l}^{\mathrm{c}}$ & \\
\hline Mineral weathering ${ }^{\mathrm{b}, 38,63}$ & $20-250 \mathrm{mg} / 1$ & Highly variable \\
\hline
\end{tabular}

${ }^{\mathrm{a}}$ Authors concluded that fissured bedrock may be responsible for such elevated level. ${ }^{\mathrm{b}}$ Taking nitrification and denitrification into account. ${ }^{c}$ Leaching from open-pit mines.

collection and the effect of nitrate contamination also hampers the progress with the proposed management framework. Therefore, there is a need to develop a holistic framework to identify the source, which could add-on to the management framework proposed by Alma$\mathrm{sri}^{40}$. This holistic approach makes use of the available methodologies to arrive at a conclusion regarding the source of nitrate in groundwater. Certain aspects of this framework are discussed in detail in the following sections.

\section{Background data collection}

Background data collection is an important and established step before starting a detailed study. This data need to be collected from local government authorities, study reports, research articles and reports from other relevant departments. Moreover, a reconnaissance survey of the identified affected areas should also be done, which will help in better understanding of the topography and presence of rivers, drains, waste dumping sites, connectivity to sewer, sanitation practices, water level in dug wells, and various anthropogenic activities close to the adversely affected areas. The survey must also study for any possible health impacts due to nitrate contamination in the affected area. Furthermore, representative samples must be collected to look for the status of nitrate contamination in the study area ${ }^{40}$. These representative samples will help in identifying the spatial pattern of nitrate contamination and will feed as primary data to map the extent of the affected area.

\section{Analytical studies}

Once the nitrate contamination is established, it becomes important to monitor the water quality over all the seasons; this would not only re-confirm the status of conta- mination, but also help in ruling out some factors over seasonal behaviour. Further, the holistic approach must include the following methodologies.

Water quality analysis: Regular monitoring (seasonal/monthly) of groundwater level and its quality (nitrate, various physico-chemical and bacteriological parameters, viz. pH, cations, anions, heavy metals, etc.) must be done. Fluctuation in water level and its correlation with nitrate concentration may indicate the leaching mechanism of nitrate into the aquifer strata and subsequently into the groundwater. The correlations of nitrate with other parameters $\left(\mathrm{Cl}^{-}, \mathrm{K}^{+}, \mathrm{SO}_{4}^{2-}\right)$ will help in understanding its origin as well ${ }^{23}$ (Table 2).

Thematic mapping: The various thematic maps like, digital elevation model, water quality parameters, water table, topography, land uses, availability of cropland, fertilizer application, etc. must be prepared for the study area $^{41}$. These maps and overlay of multiple datasets will help in understanding and confirming the spatial occurrence of nitrate and identifying the nitrate hotspots in the study area $^{42}$.

Collection and analysis of sediments: Monitoring wells must be constructed at the sites affected by elevated nitrate concentration, and during the construction of these wells, vertical sediment samples must be collected at regular depth (say every 3-5 m). Further, clay, silt and sand fraction of these sediment samples must be separated and quantified through grain size analysis to understand the lithology of the affected site. The collected sediment sample should be further analysed through X-ray diffraction (XRD) for identification of any mineral bearing nitrate or other form of nitrogen in its lattice.

Furthermore, the findings from XRD should be correlated through X-ray fluorescence (XRF) analysis. XRF study would confirm the presence of various major and trace elements in the sediment samples. Chemical 
REVIEW ARTICLE

Table 2. Commonly used methods to differentiate between geogenic and anthropogenic sources of nitrate in groundwater

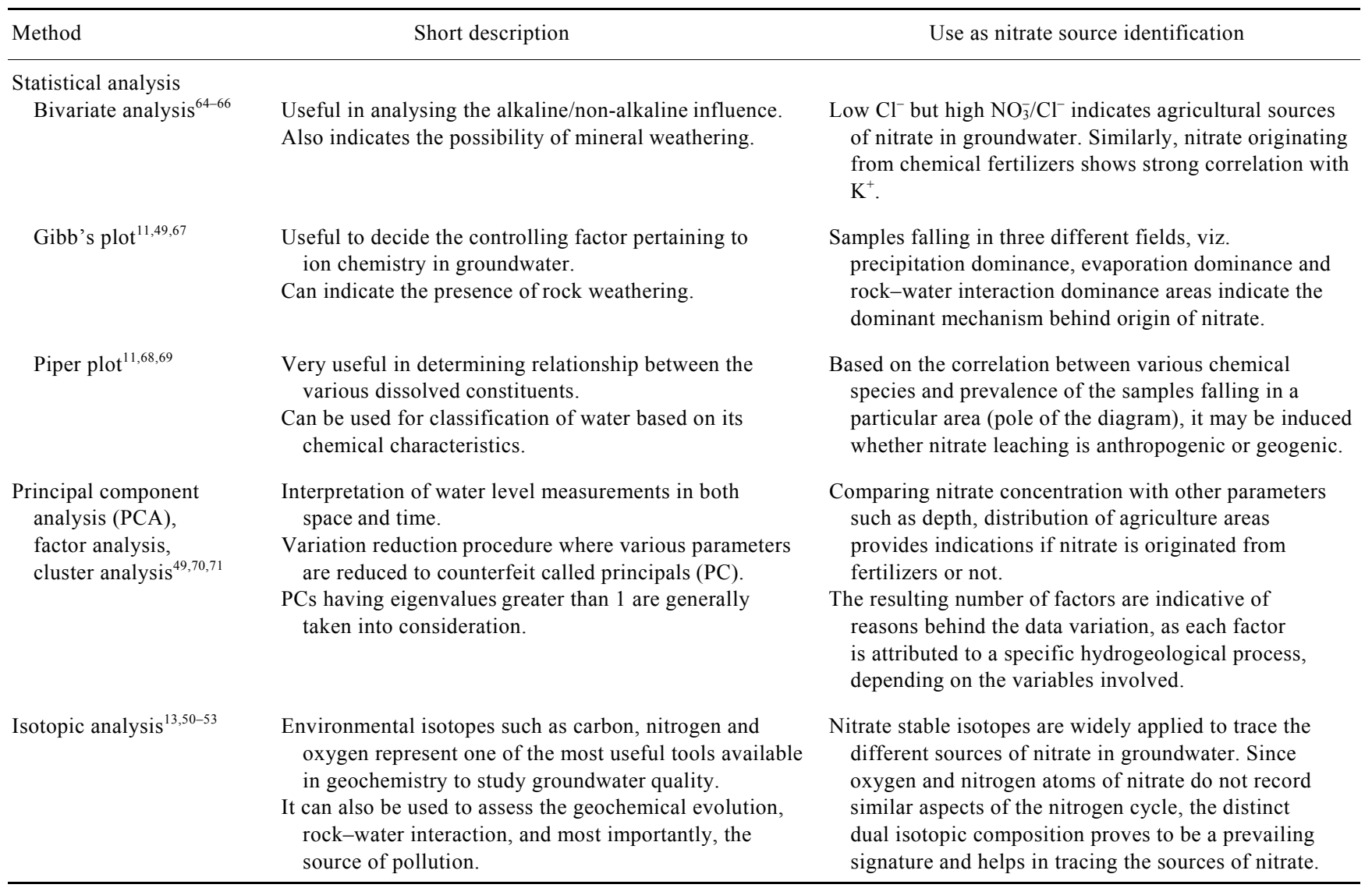

index of alteration (CIA) must also be calculated for the representative sediments. CIA values integrated with $\mathrm{XRF}$ data help in preparing the $\mathrm{A}-\mathrm{K}-\mathrm{CN}$ diagram which suggest the intensity of mineral weathering and ionic mobility in soil profile. These results will further help in understanding the leaching mechanism of nitrate into the groundwater $^{43,44}$.

Fertilizer loading calculations: The fertilizer-loading rate must be correlated with the nitrate concentration in both the nitrate affected and non-affected areas. This will narrow down the possibility of nitrate leaching from fertilizers. Furthermore, the fertilizer application rate modelling through GIS, fuzzy logic and other numerical methods will help in better fertilizer management ${ }^{45}$.

Design of septic tanks: Studies have shown that nitrate can contaminate the groundwater through leakage of septic tanks. Inspection for any possible leakage from septic tanks, sewer pipes, pit latrines must be done, especially in areas with onsite sewage disposal systems ${ }^{46}$. Mathematical and GIS modelling (as discussed above) must be done to analyse the extent of nitrate leaching. Groundwater modelling: Groundwater modelling using MODFLOW and other such modelling software helps in management of groundwater and surface water resources ${ }^{47}$. Determination of groundwater flow and study of the contaminant behaviour in a particular aquifer is important to assess the extent of groundwater pollution in various aquifers. The modelling data will help in analysing the flow direction of groundwater and subsequent management of groundwater resources.

Specific source differentiation methods: Various statistical tools such as PCA, bivariate analysis, Gibb's diagram, etc. and analytical methods such as isotopic analysis, GIS mapping, are available for source identification of nitrate in groundwater, and are suitable to differentiate between the geogenic and anthropogenic source ${ }^{48,49}$. Table 2 presents a comparison of some of the most commonly accepted and used methodologies. It can be inferred that isotopic analysis is one of the best methods available for source differentiation and hence, stable isotope abundance of nitrate has frequently been used to identify nitrate origins. However, $\delta^{15} \mathrm{~N}_{\mathrm{NO}_{3}^{-}}$from different origins shows overlapping ranges ${ }^{50,51}$. Moreover, it is hard to distinguish between nitrification or denitrification using only $\delta^{15} \mathrm{~N}_{\mathrm{NO}_{3}^{-}}$because of significant nitrogen fractionation, which happens during these processes ${ }^{52}$. Hence, additional measurement of $\delta^{18} \mathrm{O}_{\mathrm{NO}_{3}^{-}}$is required to 


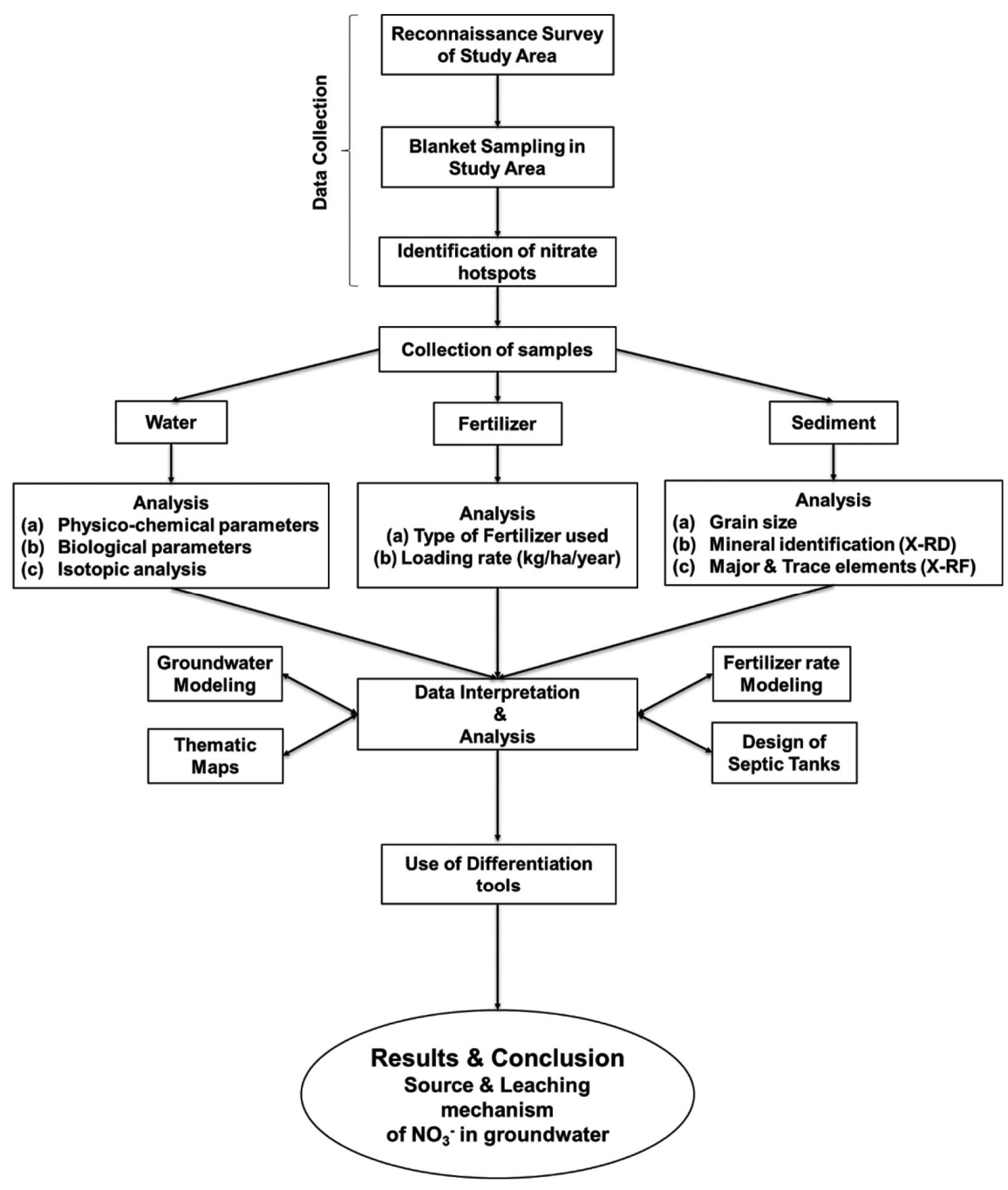

Figure 6. Holistic framework for analysis of nitrate pollution in groundwater.

obtain much more precise information about the origin of nitrate ${ }^{53}$, especially in areas where nitrogenous fertilizers are used extensively ${ }^{52}$. Moreover, when the datasets have varying nitrate levels, integration of two or more methods becomes much more informative. Simultaneous application of correlation matrix with PCA proves to be useful in examining the variance in any large dataset, as PCA reduces the dimensionality of variables ${ }^{54}$. Similarly, the spatial and seasonal variations in the contributions of dominant nitrate sources can be easily recognized through integration of groundwater hydrochemistry and nitrate isotopic composition ${ }^{55}$. The availability of resources also plays an important role in deciding the methodology to be adopted for source differentiation. As, isotopic analysis is expensive and is not available in all the countries, it becomes prudent to go for other statistical approaches. Moreover, certain restrictions pertaining to isotopic characteristics can also be overcome when statistical approaches are combined with major cations and anions ${ }^{55}$.

A summary of these approaches towards preparing a holistic framework is shown in Figure 6. The comprehen- sive study suggested in this framework shall be carried out on case-to-case basis to analyse the sources and leaching mechanisms of elevated levels of nitrate in the groundwater of the affected areas.

\section{Conclusion}

Nitrate is one of the major contaminants of drinking water in most of the areas around the world. Occurrence of elevated nitrate concentration in groundwater is governed by various complex biogeochemical processes, which makes the assessment of source a complex exercise. Many researchers incorporated the use of statistical tools and isotopic analysis to differentiate between the anthropogenic and geogenic sources of nitrate contamination in groundwater. However, there are certain limitations to these methods and a more comprehensive methodology needs to be incorporated while studying the source of leaching and mechanism. Moreover, the importance of geogenic factors and detailed studies for the same is somewhat neglected. Isotopic studies may prove better in 


\section{REVIEW ARTICLE}

deciphering the origin of nitrate in groundwater, but statistical tools will fare better in understanding the leaching mechanism. Hence, the proposed framework and differentiation methods shall be adopted on case-to-case basis and special emphasis shall be given towards the possible contribution of geogenic factors behind the elevated nitrate levels. This holistic approach would also act as a road map towards developing the technology in obtaining the nitrate-free drinking water.

1. Spalding, R. F. and Exner, M. E., Occurrence of nitrate in groundwater. J. Environ. Qual., 1993, 22, 392-402.

2. Widory, D., Kloppmann, W., Chery, L., Bonnin, J., Rochdi, H. and Guinamant, J.-L., Nitrate in groundwater: an isotopic multitracer approach. J. Contam. Hydrol., 2004, 72, 165-188.

3. Shomar, B., Osenbrück, K. and Yahya, A., Elevated nitrate levels in the groundwater of the Gaza strip: distribution and sources. Sci. Total Environ., 2008, 398, 164-174.

4. Devic, G., Djordjevic, D. and Sakan, S., Natural and anthropogenic factors affecting the groundwater quality in Serbia. Sci. Total Environ., 2014, 468-469, 933-942.

5. Wongsanit, J., Teartisup, P., Kerdsueb, P., Tharnpoophasiam, P. and Worakhunpiset, S., Contamination of nitrate in groundwater and its potential human health: a case study of lower Mae Klong river basin, Thailand. Environ. Sci. Pollut. Res., 2015, 22, 11504-11512.

6. Panno, S. V., Kelly, W. R., Martinsek, A. T. and Hackley, K. C., Estimating background and threshold nitrate concentrations using probability graphs. Ground Water, 2006, 44(5), 697-709.

7. Lundberg, J. O. et al., Nitrate and nitrite in biology, nutrition and therapeutics. Nat. Chem. Biol., 2009, 5(12), 865-869.

8. WHO, Guidelines for Drinking-Water Quality, World Health Organization, Geneva, 2011, Fourth Edition; http://www. who.int/water_sanitation_health/dwq/guidelines/en/ (accessed 10 April 2017)

9. EPA, National Primary Drinking Water Regulations, Washington DC, 2012; https://www.epa.gov/ground-water-and-drinking-water/ national-primary-drinking-water-regulations (accessed 26 September 2017).

10. Sadeq, M., Moe, C. L., Attarassi, B., Cherkaoui, I., Elaouad, R. and Idrissi, L., Drinking water nitrate and prevalence of methemoglobinemia among infants and children aged 1-7 years in Moroccan areas. Int. J. Hyg. Environ. Health, 2008, 211, 546-554.

11. Batabyal, A. K., Hydrogeochemistry and quality of groundwater in a part of Damodar Valley, Eastern India: an integrated geochemical and statistical approach. Stoch. Env. Res. Risk. A, 2018, 32, 2351-2368.

12. Kawo, N. S. and Karuppannan, S., Groundwater quality assessment using water quality index and GIS technique in Modjo River Basin, Central Ethiopia. J. Afr. Earth Sci., 2018, 147, 300-311.

13. Ogrinc, N., Tamše, S., Zavadlav, S., Vrzel, J. and Jin, L., Evaluation of geochemical processes and nitrate pollution sources at the Ljubljansko polje aquifer (Slovenia): a stable isotope perspective. Sci. Total Environ., 2019, 646, 1588-1600.

14. Wakida, F. T. and Lerner, D. N., Non-agricultural sources of groundwater nitrate: a review and case study. Water Res., 2005, 39, 3-16.

15. Rivett, M. O., Russ, S. R., Morgan, P., Smith, J. W. N. and Bemment, C. D., Nitrate attenuation in groundwater: a review of biogeochemical controlling processes. Water Res., 2008, 42, 4215-4232.

16. Weinhold, B. J., Power, J. F. and Doran, J. W., Agricultural accomplishments and impending concerns. Soil Sci., 2000, 165, 1330.

17. Miyamoto, C., Ketterings, Q., Cherney, J. and Kilcee, T., Nitrogen fixation, agronomy fact sheet series, 2008; http://nmsp.cals. cornell.edu/publications/factsheets/factsheet39.pdf (accessed 10 October 2017).

18. Gardner, W. S., McCarthy, M. J., An, S., Sobolev, D., Sell, K. S. and Brock, D., Nitrogen fixation and dissimilatory nitrate reduction to ammonium (DNRA) support nitrogen dynamics in Texas estuaries. Limnol. Oceanogr., 2006, 51(1, part 2), 558-568.

19. Wannicke, N., Korth, F., Liskow, I. and Voss, M., Incorporation of diazotrophic fixed $\mathrm{N}_{2}$ by mesozooplankton - case studies in the southern Baltic Sea. J. Marine. Syst., 2013, 117-118, 1-13.

20. Self, R. and Waskom, R. M., Nitrates in drinking water, fact sheet no. 0.517 crop series soil, 2014; http://extension.colostate.edu/ docs/pubs/crops/00517.pdf (accessed 18 October 2016).

21. Galloway, J. N. et al., Nitrogen cycles: past, present, and future. Biogeochemistry, 2004, 70, 153-226.

22. Zhou, W. et al., Autotrophic denitrification for nitrate and nitrite removal using sulphur-limestone. J. Environ. Sci., 2011, 23(11), 1761-1769.

23. Suthar, S., Bishnoi, P., Singh, S., Mutiyar, P. K., Nema, A. K. and Patil, N. S., Nitrate contamination in groundwater of some rural areas of Rajasthan, India. J. Hazard. Mater., 2009, 171, 189199.

24. Lapworth, D. J., Krishan, G., MacDonald, A. M. and Rao, M. S., Groundwater quality in the alluvial aquifer system of northwest India: new evidence of the extent of anthropogenic and geogenic contamination. Sci. Total Environ., 2017, 599-600, 1433-1444.

25. Venterea, R. T., Maharjan, B. and Dolan, M. S., Fertilizer source and tillage effects on yield-scaled nitrous oxide emissions in a corn cropping system. J. Environ. Qual., 2011, 40, 1521-1531.

26. Vinod, P. N., Chandramouli, P. N. and Koch, M., Estimation of nitrate leaching in groundwater in an agriculturally used area in the State Karnataka, India, using existing model and GIS. Aquatic Procedia, 2015, 4, 1047-1053.

27. Gheysari, M., Mirlatifi, S. M., Homaee, M., Asadi, M. E. and Hoogenboom, G., Nitrate leaching in a silage maize field under different irrigation and nitrogen fertilizer rates. Agric. Water Manage., 2009, 96, 946-954.

28. Giammarino, M. and Quatto, P., Nitrates in drinking water: relation with intensive livestock production. J. Prev. Med. Hyg., 2015, 56, 187-189.

29. Eiswirth, M., Hötzl, H. and Burn, L. S., Development scenarios for sustainable urban water systems. In Groundwater: Past Achievements and Future Challenges (ed. Sililo, O. et al.), Balkema, Rotterdam, 2000, pp. 917-922.

30. Wang, L., Ming, Y., Rios, J. F., Fernandes, R., Lee, P. Z. and Hicks, R. W., Estimation of nitrate load from septic systems to surface water bodies using an ArcGIS-based software. Environ. Earth Sci., 2013; doi:10.1007/s12665-013-2283-5.

31. McCray, J. E., Kirkland, S. L., Siegrist, R. L. and Thyne, G. D., Model parameters for simulating fate and transport of on-site wastewater nutrients. Ground Water, 2005, 43(4), 628-639.

32. Lourenço, N. D., Novais, J. M. and Pinheiro, H. M., Reactive textile dye colour removal in a sequencing batch reactor. Water Sci. Technol., 2000, 42(5-6), 321-328.

33. Plumb, J. J., Bell, J. and Stuckey, D. C., Microbial populations associated with treatment of an industrial dye effluent in an anaerobic baffled reactor. Appl. Environ. Microb., 2001, 67(7), 3226-3235.

34. Resende, A. A., eSilva, V. C. and deLima, H. M., Study of nonconventional fuels for explosives mixes. R. Esc. Minas., Ouro. Preto., 2014, 67(3), 297-302.

35. Stüeken, E. E., Kipp, M. A. and Koehler, M. C., The evolution of Earth's biogeochemical nitrogen cycle. Earth Sci. Rev., 2016, 160, 220-239; doi:10.1016/j.earscirev.2016.07.007.

36. Holloway, J. M. and Dahlgren, R. A., Nitrogen in rock: occurrences and biogeochemical implications. Global. Biogeochem. Cy., 2002, 16(4), 1118:65, 1-17. 
37. Holloway, J. M. and Smith, R. L., Nitrogen and carbon flow from rock to water: Regulation through soil biogeochemical processes, Mokelumne River watershed, California, and Grand Valley, Colorado. J. Geophys. Res., 2005, 110(F01010); doi:10.1029/ 2004JF000124.

38. Gupta, A. et al., Nitrate contamination of riverbank filtrate at Srinagar, Uttarakhand, India: a case of geogenic mineralization. J. Hydrol., 2015, 531(3), 626-637.

39. Power, J. F., Bond, J. J., Sandoval, F. M. and Willis, W. O., Nitrification in Paleocene shale. Science, 1974, 183, 1077-1079.

40. Almasri, M. N., Nitrate contamination of groundwater: a conceptual management framework. Environ. Impact Assess., 2007, 27, 220-242.

41. Schot, P. P. and Pieber, S. M., Spatial and temporal variations in shallow wetland groundwater quality. J. Hydrol., 2012, 422-423, $43-52$.

42. Buvaneshwari, S. et al., Groundwater resource vulnerability and spatial variability of nitrate contamination: insights from high density tubewell monitoring in a hard rock aquifer. Sci. Total Environ., 2017, 579, 838-847.

43. Krishna, A. K., Murthy, N. N. and Govila, P. K., Multielement analysis of soils by wavelength dispersive X-ray fluorescence spectrometry. Atom. Spectrosc., 2007, 28(6), 202-214.

44. Kumar, S. and Saxena, A., Chemical weathering of the IndoGangetic alluvium with special reference to release of fluoride in the groundwater, Unnao district, Uttar Pradesh. J. Geol. Soc. India, 2011, 77, 459-477.

45. Papadopoulos, A., Kalivas, D. and Hatzichristos, T., GIS Modelling for site-specific nitrogen fertilization towards soil sustainability. Sustainability, 2015, 7, 6684-6705.

46. Vinger, B., Hlophe, M. and Selvaratnam, M., Relationship between nitrogenous pollution of borehole waters and distances separating them from pit latrines and fertilized fields. Life Sci. J., 2012, 9(1), 402-407.

47. Maheswaran, R. et al., Regional scale groundwater modelling study for Ganga River Basin. J. Hydrol., 2016, 541(Part B), 727741; doi:http://dx.doi.org/10.1016/j.jhydrol.2016.07.029.

48. Suárez, S. P., Peiffer, S. and Gebauer, G., Origin and fate of nitrate runoff in an agricultural catchment: Haean, South Koreacomparison of two extremely different monsoon seasons. Sci. Total Environ., 2016, 648, 66-79.

49. Rezaei, M., Nikbakht, M. and Shakeri, A., Geochemistry and sources of fluoride and nitrate contamination of groundwater in Lar area, south Iran. Environ. Sci. Pollut. R, 2017, 24(18), 1547115487; doi:10.1007/s11356-017-9108-0.

50. Xue, D. et al., Present limitations and future prospects of stable isotope methods for nitrate source identification in surface- and groundwater. Water Res., 2009, 43(5), 1159-1170.

51. Koh, D. C., Mayer, B., Lee, K. S. and Ko, K. S., Land-use controls on sources and fate of nitrate in shallow groundwater of an agricultural area revealed by multiple environmental tracers. J. Contam. Hydrol., 2010, 118, 62-78.

52. Wassenaar, L. I., Evaluation of the origin and fate of nitrate in the Abbotsford Aquifer using the isotopes of ${ }^{15} \mathrm{~N}$ and ${ }^{18} \mathrm{O}$ in $\mathrm{NO}_{3}^{-}$. Appl. Geochem., 1995, 10, 391-405.

53. Silva, S. R., Kendall, C., Wilkison, D. H., Ziegler, A. C., Chang, C. C. Y. and Avanzino, R. J., A new method for collection of nitrate from fresh water and the analysis of nitrogen and oxygen isotope ratios. J. Hydrol., 2000, 228, 22-36.

54. Helena, B., Pardo, R., Vega, M., Barrado, E., Fernandez, J. M. and Fernandez, L., Temporal evolution of groundwater composition in an alluvial aquifer (Pisuerga River, Spain) by principal component analysis. Water Res., 2000, 34(3), 807-816.

55. Meghdadi, A. and Javar, N., Quantification of spatial and seasonal variations in the proportional contribution of nitrate sources using a multi-isotope approach and Bayesian isotope mixing model. Environ. Pollut., 2018, 235, 207-222.
56. Dahan, O., Babad, A., Lazarovitch, N., Russak, E. E. and Kurtzman, D., Nitrate leaching from intensive organic farms to groundwater. Hydrol. Earth Syst. Sci., 2014, 18, 333-341.

57. Banks, D., Karnachuk, O. V., Parnachev, V. P., Holden, W. and Frengstad, B., Groundwater contamination from rural pit latrines: examples from Siberia and Kosova. J. Chartered. Inst. Water. Environ. Manage., 2002, 16(2), 147-152.

58. Dzwairo, B., Hoko, Z., Love, D. and Guzha, E., Assessment of the impacts of pit latrines on groundwater quality in rural areas: a case study from Marondera district, Zimbabwe. Phys. Chem. Earth, 2006, 31(15-16), 779-788.

59. Pujari, P. R., Padmakar, C., Labhasetwar, P. K., Mahore, P. and Ganguly, A. K., Assessment of the impact of on-site sanitation systems on groundwater pollution in two diverse geological settings-a case study from India. Environ. Monit. Assess., 2012, 184(1), 251-263.

60. Feichtinger, F., Smidt, S. and Klaghofer, E., Water and nitrate fluxes at a forest site in the north Tyrolean Limestone Alps. Environ. Sci. Pollut. Res., 2002, 2, 31-36.

61. Miller, W. W., Johnson, D. W., Denton, C., Verburg, P. S. J., Dana, G. L. and Walker, R. F., Inconspicuous nutrient laden surface runoff from mature forest Sierran watersheds. Water Air Soil Poll., 2005, 163, 3-17.

62. Mikac, N., Cosovic, B., Ahel, M., Andreis, S. and Toncic, Z., Assessment of groundwater contamination in the vicinity of a municipal solid waste landfill (Zagreb, Croatia). Water Sci. Technol., 1998, 37(8), 37-44.

63. Galloway, J. N. et al., The nitrogen cascade. Bioscience, 2003, 53(4), 341-356.

64. Li, P., Li, X., Meng, X., Li, M. and Zhang, Y., Appraising groundwater quality and health risks from contamination in a semiarid region of Northwest China. Expos. Health, 2016, 8(3), 361-379.

65. Matiatos, I., Nitrate source identification in groundwater of multiple land-use areas by combining isotopes and multivariate statistical analysis: a case study of Asopos basin (Central Greece). Sci. Total Environ., 2016, 541, 802-814.

66. Anornu, G., Gibrilla, A. and Adomako, D., Tracking nitrate sources in groundwater and associated health risk for rural communities in the white Volta River basin of Ghana using isotopic approach $\left(\delta^{15} \mathrm{~N}, \delta^{18} \mathrm{ONO}_{3}^{-}\right.$and $\left.{ }^{3} \mathrm{H}\right)$. Sci. Total Environ., 2017, 603-604, 687-698.

67. Gibbs, R. J., Mechanism controlling world water chemistry. Science, 1970, 170, 795-840.

68. Piper, A. M., A graphical procedure in the geochemical interpretation of water analyses, transactions. Am. Geophys. Union, 1944, 25, 914-928.

69. Nazzal, Y. et al., A pragmatic approach to study the groundwater quality suitability for domestic and agricultural usage, Saq aquifer, northwest of Saudi Arabia. Environ. Monit. Assess., 2014, 186(8), 4655-4667; doi:10.1007/s10661-014-3728-3.

70. Kaiser, H. F., The application of electronic computers to factor analysis. Educ. Psychol. Meas., 1960, 20, 141-151.

71. Winter, T. C., Mallory, S. E., Allen, T. R. and Rosenberry, D. O., The use of principal component analysis for interpreting ground water hydrographs. Ground Water, 1999, 38(2), 234-246.

72. DeRoos, A. J., Ward, M. H., Lynch, C. F. and Cantor, K. P., Nitrate in public water supplies and the risk of colon and rectum cancers. Epidemiology, 2003, 14, 640-649.

73. Ashok, V. and Hait, S., Remediation of nitrate-contaminated water by solid-phase denitrification process - a review. Environ. Sci. Pollut. Res., 2015, 22(11), 8075-8093; doi:10.1007/s11356-0154334-9.

Received 25 May 2019; revised accepted 8 January 2020

doi: $10.18520 / \mathrm{cs} / \mathrm{v} 118 / \mathrm{i} 6 / 883-891$ 